\title{
mRNA Delivery through Fibronectin Associated Liposome-Apatite Particles: A New Approach for Enhanced mRNA Transfection to Mammalian Cell
}

\author{
Fatema Tuj Zohra, ${ }^{a, \dagger}$ Yoshie Maitani, ${ }^{b}$ and Toshihiro Akaike*,a \\ ${ }^{a}$ Department of Biomolecular Engineering, Graduate School of Bioscience and Biotechnology, Tokyo Institute of Tech- \\ nology; 4259 Nagatsuta-cho, Midori-ku, Yokohama 226-8501, Japan: and ${ }^{b}$ Fine Drug Targeting Research Laboratory, \\ Institute of Medicinal Chemistry, Hoshi University; 2-4-41 Ebara, Shinagawa-ku, Tokyo 142-8501, Japan. \\ Received July 8, 2011; accepted October 13, 2011; published online October 26, 2011
}

It was believed for a long time that mRNA is very unstable, and can not be used for therapeutic purposes. In the last decade, however, many research groups proved its transfection feasibility along with advantages and applications. Our investigation is aimed at establishing a potent and efficient mRNA delivery system. We previously reported that an inorganic-organic hybrid carrier by exploiting the advantages of inorganic nano apatite particles onto organic carrier DOTAP $\{N$-[1-(2,3-dioleoloxy)propyl $]-N, N, N$-trimethyl ammonium chloride\} and showed potential effect of carbonate apatite particles on each of the mRNA delivery steps in dividing and non-dividing cell. Here, we report on the development of a more efficient mRNA carrier by complexing ECM protein, fibronectin with the DOTAP-apatite carrier. The carrier showed enhanced uptake of luciferase mRNA both qualitatively and quantitatively. Accelerated cellular endocytosis rate was evaluated using labeled endosome. Finally expression of lucifearse mRNA was higher for fibronectin complexed carrier in compared to the uncoated one.

Key words mRNA delivery; cationic lipid; carbonate apatite; fibronectin

mRNAis a relatively novel tool in gene delivery. This is due to the fact that it has been considered too labile to ensure protein expression. Numerous studies have demonstrated the contrary; not only is mRNA capable of tolerating the impact of transfection protocols and of being translated efficiently ${ }^{1-7)}$; it also has some advantages over DNA. mRNA as a gene delivery tool is a very good alternative way to treat those cells where DNA based gene expression is little or very low due to the absence of cell cycle-dependent breakdown of the nuclear envelop. ${ }^{8,9)}$ The higher safety, due to the avoidance of genomic insertion, and no need to provide for a promoter and a terminator decide in favor of mRNA. Moreover mRNA is deprived of immunogenic $\mathrm{CpG}$ motifs, and hence displays reduced immunogenic effects. ${ }^{10,11)}$ When combined with the aforementioned advantages, this property makes it even more attractive to apply mRNA in the context of gene delivery. mRNA based expression of certain protein sustains for a limited time but such transient expression is desirable in some clinical disorders specially neurological disorders. ${ }^{12,13)}$ Vaccination with mRNA is definitely another broad area of application due to the superiority of mRNA compared to DNA or proteins in inducing an immune response as shown by many research groups. $^{14-19)}$

These studies imply mRNA-based gene delivery is growing huge interest for some pathological recovery and cancer vaccination and thus, further improvement of mRNA carrier is highly desirable.

Extracellular matrix (ECM) protein and adhesion molecules have been used for DNA based gene delivery. The argininglycine-aspartic acid (RGD) sequence is well known to serve as a recognition motif in multiple ligands for several different integrins such as integrin $\alpha \mathrm{v} \beta 3$ and $\alpha 5 \beta 1$ etc. $^{20)}$ RGD-modified

${ }^{\dagger}$ Present address: Fine Drug Targeting Research Laboratory, Institute of Medicinal Chemistry, Hoshi University; 2-4-41 Ebara, Shinagawa-ku, Tokyo 142-8501, Japan. liposomes ${ }^{21,22)}$ and polymers ${ }^{23,24)}$ have been developed as gene transfer vectors. An electrostatic complex consisting of a cationic liposome, an integrin $\alpha 5 \beta 1$-targeting peptide, and plasmid DNA, was efficiently transfected to tumor cells. ${ }^{25,26)}$ On the other hand, ECM proteins, especially collagen 1 and fibronectin which are intrinsically involved in development, homeostasis, and maintenance of bone or tooth, closely associate with deposited calcium phosphate $(\mathrm{CaP})$ ceramics and thus act as scaffold for neighboring cells. ${ }^{27-31)}$ ECM molecules have the inherent tendency of binding to the charged surface of $\mathrm{CaP}$ derivatives by electrostatic interactions. Based on this natural phenomena, it has been reported that calcium phosphate/DNA complex with ECM proteins, especially collagen and fibronectin, led to remarkably high transgene expression in mammalian cells. ${ }^{32}$

We previously reported on a hybrid carrier by embedding inorganic nano-particles of carbonate apatite onto liposomal carrier $N$-[1-(2,3-dioleoloxy)propyl]- $N, N, N$-trimethyl ammonium chloride (DOTAP) and demonstrated its high transfection potency of Luciferase mRNA both in mitotic and non-mitotic cells. ${ }^{3)}$ We report here for the first time on the development of surface-functional composites of DOTAP-apatite with the help of fibronectin and succeed in enabling rapid cellular endocytosis and high luciferase-mRNA delivery in cytoplasm and eventual enhancement in transgene expression.

\section{MATERIALS AND METHODS}

Cell Culture HeLa cell lines were cultured in $25-\mathrm{cm}^{2}$ flasks in Dulbecco's modified Eagle's medium (DMEM) supplemented with $10 \%$ fetal bovine serum (FBS), $50 \mu \mathrm{g}$ penicil$\mathrm{lin} / \mathrm{mL}, 50 \mu \mathrm{g}$ streptomycin $/ \mathrm{mL}$ and $100 \mathrm{~g}$ neomycin $/ \mathrm{mL}$ at $37^{\circ} \mathrm{C}$ in a humidified $5 \% \mathrm{CO}_{2}$ containing atmosphere.

Synthesis of mRNA Transcripts mRNA encoding luciferase was prepared by in vitro transcription of the luciferase SP6 control DNA having a poly(A) tail [A30] (Promega, 
U.S.A.) using an SP6 RiboMAX ${ }^{\mathrm{TM}}$ kit as described by the manufacturer (Promega) with or without $\mathrm{m} 7 \mathrm{G}\left(5^{\prime}\right) \mathrm{pppG}\left(5^{\prime}\right)$ cap analog (Ambion, U.S.A.) at a ratio of $5: 1$ cap/guanosine 5'-triphosphate (GTP). When the cap analog was omitted, the GTP concentration was raised accordingly to $5 \mathrm{~mm}$. In vitro transcribed mRNAs (with or without cap) were characterized by gel electrophoresis and were all $c a$. $1800 \mathrm{bp}$ in length. Purification of mRNA was performed by RQ1 DNase I digestion, followed by extraction with phenol:chloroform: isoamyl alcohol and precipitation by addition of sodium acetate $(\mathrm{pH}$ 5.5) and ethanol. Precipitated RNA was washed with $70 \%$ ethanol, dissolved in water, quantified spectrophotometrically at $260 \mathrm{~nm}$ and examined by agarose gel electrophoresis after denaturation at $65^{\circ} \mathrm{C}$ for $15 \mathrm{~min}$.

Liposome Formation For the preparation of liposome, solid DOTAP, Sigma was initially dried from chloroform, subsequently dispersed in $\delta \mathrm{H}_{2} \mathrm{O}$ and shaken at a temperature above the gel-to-liquid-crystalline transition temperature of the lipid $\left(\mathrm{ca} .0^{\circ} \mathrm{C}\right)$ for $15 \mathrm{~min}$, followed by sonication of the milky solution for $10 \mathrm{~min}$.

Complex Formation Three micrograms of heat-denatured mRNA $\left(10 \mathrm{~min}\right.$ at $\left.65^{\circ} \mathrm{C}\right)$ and $6-10 \mu \mathrm{g}$ of DOTAP were diluted separately in $100 \mu \mathrm{L}$ DMEM media ( $\mathrm{pH}$ 7.5). After $15 \mathrm{~min}$, DOTAP was added to the RNA solution, followed by incubation for $15 \mathrm{~min}$ at room temperature. By adjusting final volume to $1 \mathrm{~mL}, 4 \mathrm{mM} \mathrm{CaCl}_{2}$ and 0 to $50 \mu \mathrm{g} / \mathrm{mL}$ fibronectin solution were added prior to incubation for $30 \mathrm{~min}$ at $37^{\circ} \mathrm{C}$. The solution containing each type of transfection complexes was added with $10 \%$ FBS to the rinsed cells. Treated cells were incubated at $37^{\circ} \mathrm{C}$ in a $5 \% \mathrm{CO}_{2}$ humidified environment for $2-4 \mathrm{~h}$. After $4 \mathrm{~h}$, the transfection mix was discarded and $1 \mathrm{~mL}$ of fresh serum medium was added to the cells. Cells were cultured for $6-12 \mathrm{~h}$ before analysis of reporter gene expression. The transfected cells were lysed by a lysis buffer (Promega) and the luciferase activity was measured using the luciferase assay system by a luminometer (TD-20/20 Luminometer, U.S.A.). Transfection efficiency was measured as mean light units per milligram of cell protein.

Labeling of mRNA mRNA has been labeled using fluorescein RNA labeling mix (Roche, Germany) which contains fliuorescein-12-uridine 5 -triphosphate (UTP) during in vitro transfection of luciferase control DNA according to the manufacturer's protocol. As recommended, the labeled probe was used immediately after the preparation.

Dynamic Light Scattering studies The size and zeta potential were measured by a light scattering apparatus, ELS 200TI (Otsuka Electronics, Osaka, Japan).

Flow Cytometry Fluorescein labeled mRNA containing complexes were added with $10 \%$ FBS to $80 \%$ confluent HeLa cells seeded in a 6 -well plate and incubated for $3 \mathrm{~h}$. Cells were lysed by trypsin-ethylenediaminetetraacetic acid (EDTA) and after detachment of the adherent cells centrifugation has been performed. Discarding supernatant the cell pallet was re suspended in $1 \mathrm{~mL}$ serum free DMEM media and used for EPICS XL flow cytometer (Beckman Coulter, CA, U.S.A.). The intensity of fluorescein labeled mRNA in HeLa cell was determined by gating cells at an excitation wavelength of $488 \mathrm{~nm}$ using an argon ion laser. The presence of the labeled mRNA was detected by emission at a wavelength of $525 \mathrm{~nm}$.

Confocal Microscopy The cells were grown on presterilized coverslips inside a petridish filled with the appropriate culture medium and after reaching the desired confluency the cell were transfected with fluorescein-labeled mRNA. After certain periods ( 1 to $5 \mathrm{~h}$ ), acidic compartments like endosomes were labeled with Lysotracker red DND-99 (diluted to 50$75 \mathrm{~nm}$ in phosphate buffered saline (PBS)). For labeling, the medium containing transfection mix were removed and the pre-warmed $\left(37^{\circ} \mathrm{C}\right)$ probe containing medium was added and incubated for $30 \mathrm{~min}$ at $37^{\circ} \mathrm{C}$. After removing the probe solution, fresh serum-free DMEM was added and incubated again at $37^{\circ} \mathrm{C}$ for distaining. After fixing the labeled cell using formalin they were observed under FLUOVIEW confocal laser scanning microscope (OLYMPUS).

\section{RESULTS AND DISCUSSION}

Determination of Size and Surface Charge of the Particles After the formation of mRNA-DOTAP-apatite complex with or without fibronectin, the initial characterization has been performed. It was found that particle size was gradually decreased from 660 to $361 \mathrm{~nm}$ after the complexation of mRNA-DOTAP-apatite particles with different concentrations of fibronectin (Fig. 1). We can speculate that the presence of fibronectin protects non-specific interaction with other serum proteins and also prevent aggregation of liposome particles. Zeta potential also decreased from +18 to $-10 \mathrm{mV}$ due to the complexation of fibronectin with the mRNA-DOTAPaptite particles. This strategy of significant change in size and charge clearly suggested fibronectin coating on mRNADOTAP-apatite particles. It is well known that an optimum positive charge of gene-carrier complex is the pre-requisite to bind on the cell membrane for subsequent uptake. In this regards, even though, after addition of fibronectin, the surface charge of the particles is decreased from positive to entirely negative, enhanced binding and internalization is expected due to cell surface integrin mediated uptake mechanism.

Analysis of Uptake of the Labeled Luc-mRNA In order to demonstrate whether DOTAP-apatite particles functionalized with fibronectin can facilitate enhanced delivery of labeled mRNA across the plasma membrane, we examined cellular uptake of the fluorescein labeled mRNA, following $3 \mathrm{~h}$ incubation of HeLa cells with various particle formulations. As shown in Fig. 2, while with only DOTAP, delivery of

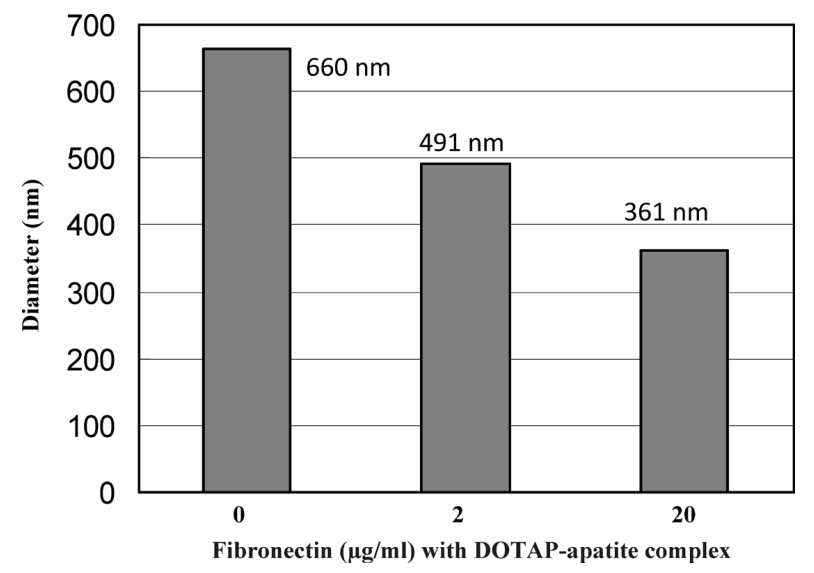

Fig. 1. Size of the Particles

DOTAP-apatite complexes with or without fibronectin $(2-20 \mu \mathrm{g} / \mathrm{mL})$ were prepared as described in the method section. Average size of three particles is presented here. 
A

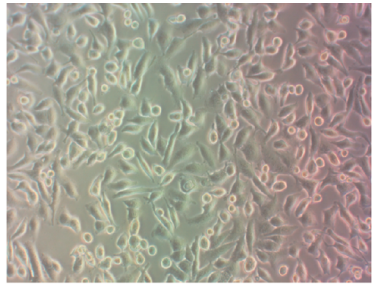

B

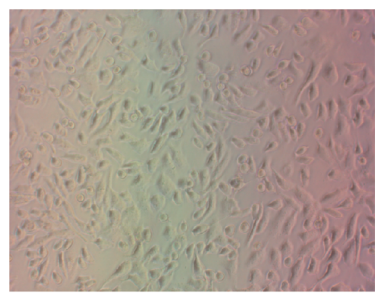

C

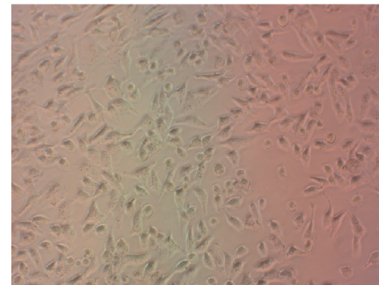

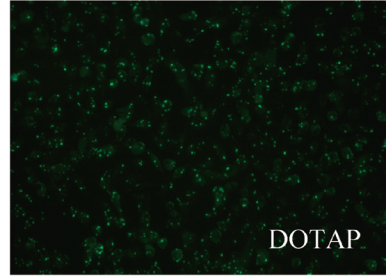
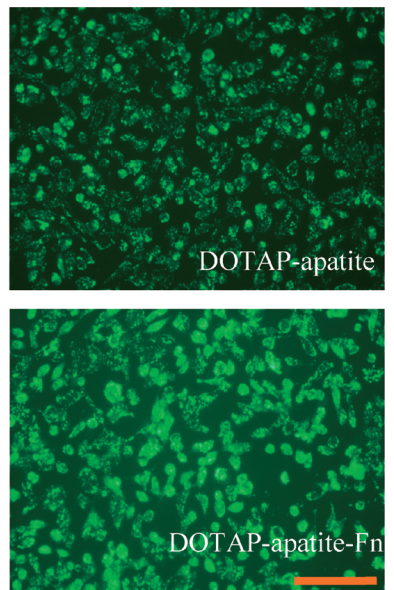

Fig. 2. Cellular Uptake Analysis of Fluorescein Labeled mRNA into HeLa Cell by DOTAP-Apatite-Fn Particles

Fluorescein labeled mRNA-DOTAP, fibronectin coated or uncoated DOTAPapatite complexes were prepared as described in the method section. Complexes were added with $10 \%$ FBS to $80 \%$ confluent HeLa cells seeded in a 24 -well plate and incubated for $4 \mathrm{~h}$. Extracellular particles were removed by EDTA prior to observation under a fluorescence microscope. Bar indicates $200 \mu \mathrm{m}$.

fluorescein labeled mRNA was very low (Fig. 2A), complexation of DOTAP with inorganic apatite resulted in significantly improved mRNA delivery (Fig. 2B). Moreover, when DOTAPapatite paricles were complexed with fibronectin and allowed to deliver particle bound mRNA, more pronounced cell associated labeled mRNA was observed (Fig. 2C). Quantitative

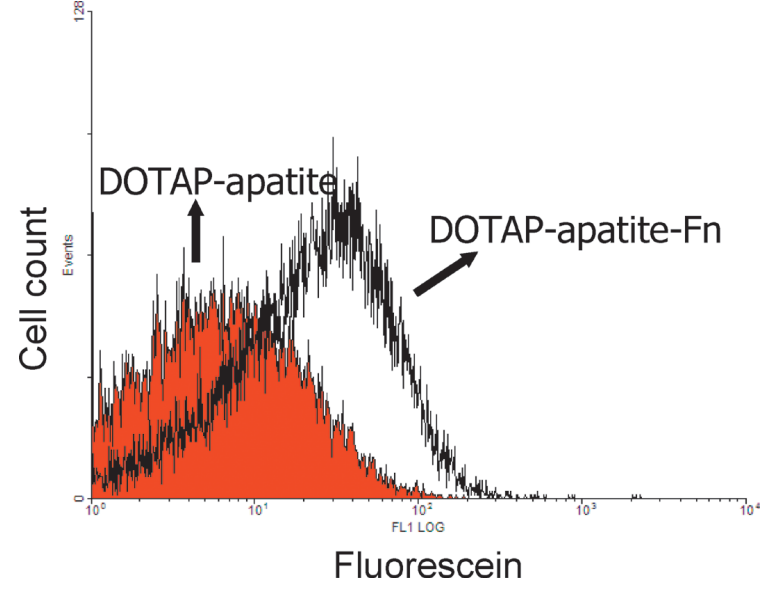

Fig. 3. Cellular Uptake Analysis by Flow Cytometry

Fibronectin coated or uncoated DOTAP-apatite complexes were prepared as described in the method section. Complexes were added with $10 \%$ FBS to $80 \%$ confluent HeLa cells seeded in a 6-well plate followed by incubation for $4 \mathrm{~h}$. Cells were treated by trypsin-EDTA and after detachment of the adherent cells centrifugation have been performed. Discarding supernatant the cell pallet was resuspended in $1 \mathrm{~mL}$ serum free DMEM media and used for flow cytometry.

analysis by flow cytometry also demonstrated the similar delivery potency by DOTAP-apatite-Fn particles compared to the particles without fibronectin (Fig. 3). This result indicates fibronectin facilitated enhanced mRNA uptake might be partly because of recognition by the extracellular domains of specific integrin molecules on the cell membrane.

For direct demonstration of endocytosis mediated internalization rather than fusion, different particles were allowed to deliver fluorescein labeled mRNA into HeLa cells (Fig. 4A) whose endosomes were stained with Lysotracker Red DND-99 probe (Fig. 4B) followed by incubation for $3 \mathrm{~h}$. As shown in Fig. 4C (upper panel), higher numbers of fluorescein labeled mRNA were associated with endosome (as viewed
A
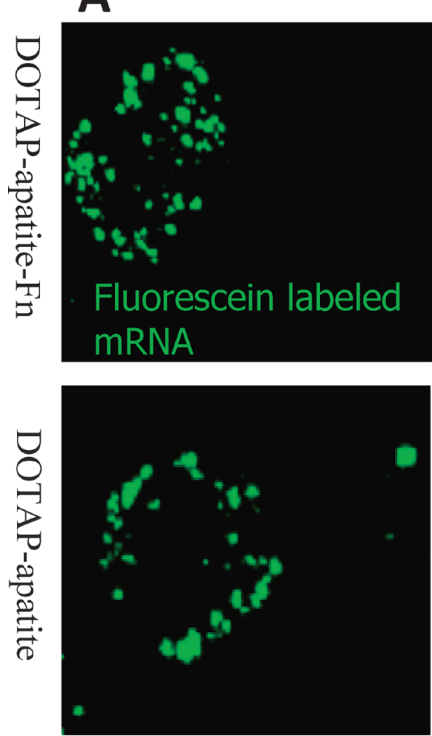

B
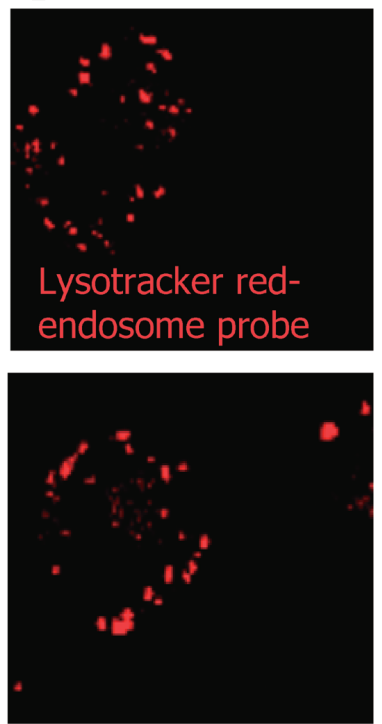

C
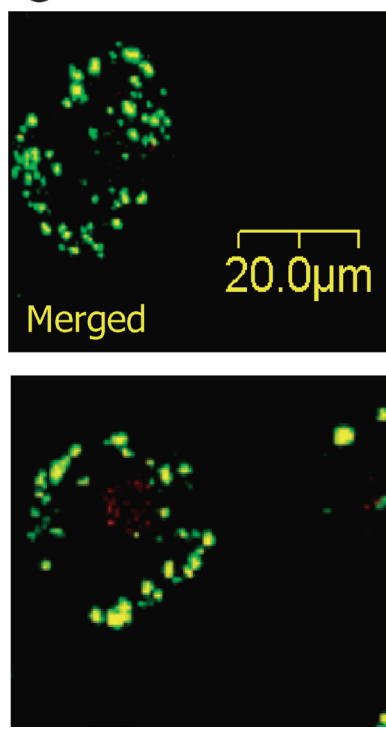

Coated one showed better localization status compared with uncoated carrier.

Fig. 4. Endosomal Localization of Labeled Luc-mRNA after $3 \mathrm{~h}$

Fluorescein labeled mRNA was allowed to form fibronectin coated mRNA-DOTAP-apatite complex where $2 \mu \mathrm{g} / \mathrm{mL}$ of fibronectin was used. The complex was added with $10 \%$ FBS to $80 \%$ confluent HeLa cells seeded on cover slips inside a petridish. After 3 h, acidic compartments like endosomes/lysosomes were stained with Lysotracker red DND-99 (diluted to 50-75 nM in PBS) and incubated for $30 \mathrm{~min}$. After replacing the labeling solution with fresh serum free medium, the cells were fixed and observed under confocal microscope. Green, red and yellow colors indicate on labeled mRNA (A), endosomes (B) and merged status (C) respectively. Bar indicates $20 \mu$ m. 
from merged status) for fibronectin complexed DOTAP-apatite particles in comparision with the uncomplexed one (Fig. 4C, lower panel). This result, is again suggesting that the receptor mediated endocytosis might caused enhanced mRNA internalization through fibronectin complexed carrier and better level of co localized mRNA within a single cell in compared to the uncomplexed one.

Analysis of the Expression Pattern of Fibronectin Coated Particles We then examined the effect of fibronectin on the trasfection efficiency of DOTAP-apatite particles by checking the gene expression pattern in HeLa cell. As stated previously that optimum concentration of DOTAP was determined for a certain amount of luiciferase mRNA in HeLa cell by applying 4 to $16 \mu \mathrm{g}$ of DOTAP along with $3 \mu \mathrm{g}$ of LucmRNA to form either mRNA-DOTAP complex or mRNADOTAP-apatite complex. ${ }^{5)}$ Then mRNA-DOTAP-apatite-Fn complexes were formed using $2-50 \mu \mathrm{g} / \mathrm{mL}$ fibronectin and all the complexes were then allowed to transfect HeLa cells. Luciferase expression was determined at $6 \mathrm{~h}$ post transfection. The expression has been enhanced around 2 times due to the presence of fibronectin on the DOTAP-apatite particles as shown in Fig. 5A. Among the different concentrations, $2 \mu \mathrm{g} /$ $\mathrm{mL}$ fibronectin showed maximum enhancement, then exhibited gradual decrease as concentration of fibronectin increases (Fig. 5A). Many parameters including size of delivery particles are known to influence transfection efficiency and larger particles are more efficient in transfection. ${ }^{33,34)}$ Thus this strategy of decreasing efficiency with increasing Fn concentration can be correlated with size of the particles. As size decreased for increasing fibronectin concentration, larger complexes with lower fibronectin value $(2 \mu \mathrm{g} / \mathrm{mL})$ exhibited maximum enhancement of the expression (Fig. 5A). On the other hand, even though bigger, DOTAP-apatite paricles had lower efficiency than the fibronectin complexed one due to better association with the cell. It is noteworthy that Fn-DOTAP-apatite particles showed more than 50 times enhanced transfection potency than the only DOTAP (the so far reported most efficient non-viral mRNA carrier). This result shows a potential way to significantly improve mRNA transfection potency over the existing liposome technology.

Fibronectin is a large $(440 \mathrm{kDa})$ multidomain extracellular matrix protein with an RGD site that is not exposed in its native compact conformation. When complexed with liposome vector, fibronectin adopts a conformation that is more open than its compact conformation. ${ }^{35)}$ This open conformation exposes a hidden RGD site in Fn that stimulates binding to adhesion molecules. In our investigation, the hidden RGD site of the fibronectin coated complex might be exposed.

Proof of Integrin-Mediated Delivery and Expression To evaluate one of the possible reasons for Fn-DOTAP-apatite mediated trans-gene delivery and expression we performed an inhibition assay adding excess amount of free $(200 \mu \mathrm{g} / \mathrm{mL})$ fibronectin to the preformed particle suspension, and incubated the cell for the same period of time as followed in usual transfection procedure. Decrease in mRNA transfection potency (Fig. 5B) indicated competitive blocking of the specific integrin receptors by free fibronectin might diminished interaction between Fn-DOTAP-apatite particles with cell membrane thus decreasing uptake and further expression too.
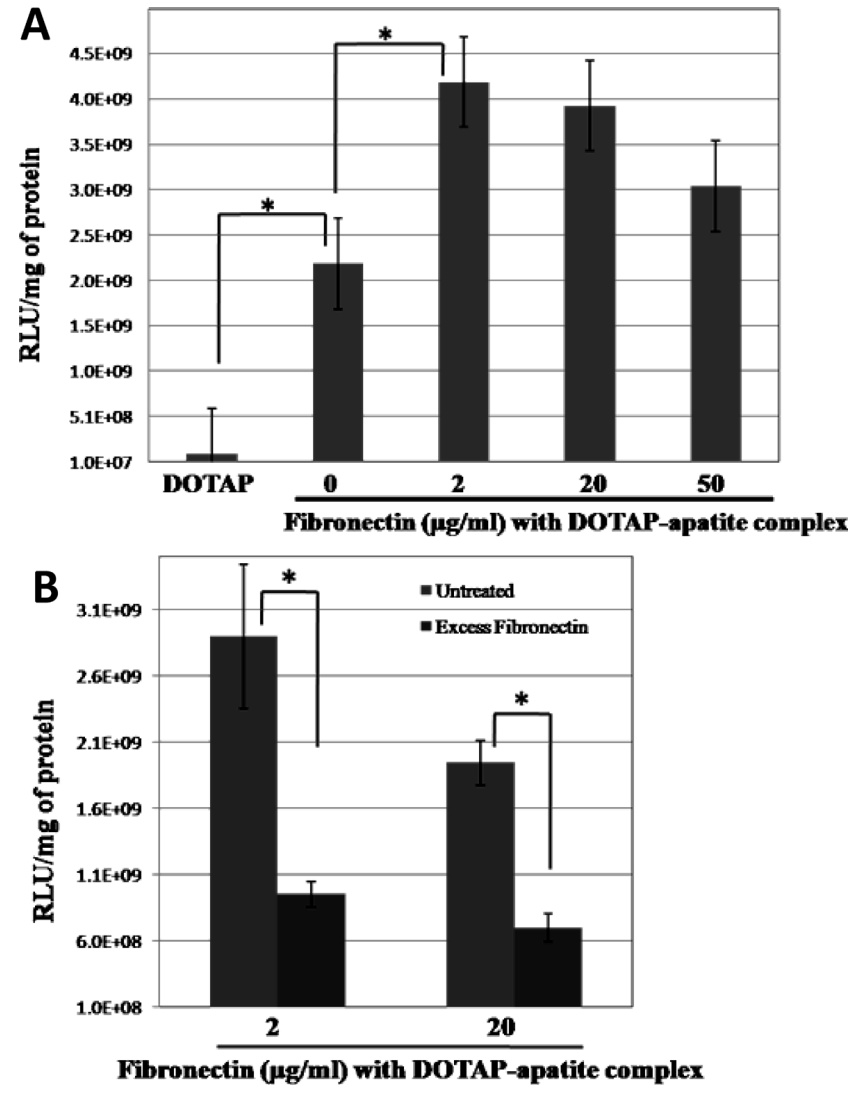

Fig. 5. Gene Expression Pattern by Fibronectin Coated DOTAP-Apatite Particles and Competitive Inhibition Assay

mRNA-DOTAP and fibronectin $(2 \mu \mathrm{g} / \mathrm{mL})$ coated or uncoated mRNA-DOTAPapatite complexes were prepared as described in the text. Complexes were transferred with $10 \%$ FBS to $80 \%$ confluent $\mathrm{HeLa}$ cells seeded in 24 well plate and incubated for $3 \mathrm{~h}(\mathrm{~A})$. After the addition of $10 \%$ FBS into the complex containing solution, excess fibronectin $(200 \mu \mathrm{g} / \mathrm{mL})$ was added and then the whole solution was added to $80 \%$ confluent HeLa cells seeded in 24 well plate (B). Luciferase mRNA expression was measured at $6 \mathrm{~h}$ post transfection. Luciferase activity was measured as RLU/mg of protein. * indicates $p<0.05$ versus untreated control.

\section{CONCLUSION}

Simple fabrication to attain improved tranfection potency is one of the important criteria for designing a better carrier. We could fabricate our developed mRNA carrier with the cell recognizable protein like fibronectin. This is the first time report of inorganic-organic hybrid mRNA carrier by ECM protein. Thus, we have established a superior mRNA transfection methodology based on anchoring liposome bound nano-apatite particles with the ECM protein that possibly could effectively associate with the cell membrane allowing better internalization and subsequent expression.

Acknowledgment This work was supported in parts by Grants-in-Aid for Scientific Research from the Ministry of Education, Culture, Sports, Science and Technology of Japan.

\section{REFERENCES}

1) Zou S, Scarfo K, Nantz MH, Hecker JG. Lipid-mediated delivery of RNA is more efficient than delivery of DNA in non-dividing cells. Int. J. Pharm., 389, 232-243 (2010).

2) Rejman J, Tavernier G, Bavarsad N, Demeester J, De Smedt SC. 
mRNA transfection of cervical carcinoma and mesenchymal stem cells mediated by cationic carriers. J. Control. Release, 147, 385-391 (2010).

3) Zohra FT, Chowdhury EH, Akaike T. High performance mRNA transfection through carbonate apatite-cationic liposome conjugates. Biomaterials, 30, 4006-4013 (2009).

4) Zohra FT, Chowdhury EH, Tada S, Hoshiba T, Akaike T. Effective delivery with enhanced translational activity synergistically accelerates mRNA-based transfection. Biochem. Biophys. Res. Commun., 358, 373-378 (2007).

5) Zohra FT, Chowdhury EH, Nagaoka M, Akaike T. Drastic effect of nanoapatite particles on liposome-mediated mRNA delivery to mammalian cells. Anal. Biochem., 345, 164-166 (2005).

6) Bettinger $\mathrm{T}$, Carlisle RC, Read ML, Ogris M, Seymour LW. Peptide-mediated RNA delivery: a novel approach for enhanced transfection of primary and post-mitotic cells. Nucleic Acids Res., 29, 3882-3891 (2001).

7) Karikó K, Kuo A, Barnathan E. Overexpression of urokinase receptor in mammalian cells following administration of the in vitro transcribed encoding mRNA. Gene Ther., 6, 1092-1100 (1999).

8) Pollard H, Remy JS, Loussouarn G, Demolombe S, Behr JP, Escande D. Polyethylenimine but not cationic lipids promotes transgene delivery to the nucleus in mammalian cells. J. Biol. Chem., 273, 7507-7511 (1998).

9) Brunner S, Sauer T, Carotta S, Cotten M, Saltik M, Wagner E. Cell cycle dependence of gene transfer by lipoplex, polyplex and recombinant adenovirus. Gene Ther., 7, 401-407 (2000).

10) Yew NS, Wang KX, Przybylska M, Bagley RG, Stedman M, Marshall J, Scheule RK, Cheng SH. Contribution of plasmid DNA to inflammation in the lung after administration of cationic lipid:pDNA complexes. Hum. Gene Ther., 10, 223 -234 (1999).

11) Yew NS, Zhao H, Wu IH, Song A, Tousignant JD, Przybylska M, Cheng SH. Reduced inflammatory response to plasmid DNA vectors by elimination and inhibition of immunostimulatory $\mathrm{CpG}$ motifs. Mol. Ther., 1, 255-262 (2000).

12) Anderson DM, Hall LL, Ayyalapu AR, Irion VR, Nantz MH, Hecker JG. Stability of mRNA/cationic lipid lipoplexes in human and rat cerebrospinal fluid: methods and evidence for nonviral mRNA gene delivery to the central nervous system. Hum. Gene Ther., 14 191-202 (2003).

13) Hecker JG, Hall LL, Irion VR. Nonviral gene delivery to the lateral ventricles in rat brain: initial evidence for widespread distribution and expression in the central nervous system. Mol. Ther., 3, 375384 (2001).

14) Mitchell DA, Nair SK. RNA transfected dendritic cells as cancer vaccines. Curr. Opin. Mol. Ther., 2, 176-181 (2000).

15) Kyte JA, Kvalheim G, Aamdal S, Saebøe-Larssen S, Gaudernack G. Preclinical full-scale evaluation of dendritic cells transfected with autologous tumor-mRNA for melanoma vaccination. Cancer Gene Ther., 12, 579-591 (2005).

16) Zhang HM, Zhang LW, Ren J, Fan L, Si XM, Liu WC. Induction of $\alpha$-fetoprotein-specific CD4- and CD8-mediated T-cell response using RNA-transfected dendritic cells. Cell. Immunol., 239, 144-150 (2006).

17) Qiu J, Lil GW, Sui YF, Sun YJ, Huang YY, Si SY, Ge W, Song HP. TruncatedTERT mRNA transfected dendritic cells evoke TERT specific antitumor response in vivo. Hepatogastroenterology, 54, 681-687 (2007).

18) Kyte JA, Gaudernack G. Immuno-gene therapy of cancer with tumour-mRNA transfected dendritic cells. Cancer Immunol. Immunother., 55, 1432-1442 (2006).

19) Weide B, Pascolo S, Scheel B, Derhovanessian E, Pflugfelder A,
Eigentler TK, Pawelec G, Hoerr I, Rammensee HG, Garbe C. Direct injection of protamine-protected mRNA: results of a phase $1 / 2 \mathrm{vac}-$ cination trial in metastatic melanoma patients. J. Immunother., 32, 498-507 (2009).

20) Romanov VI, Goligorsky MS. RGD-recognizing integrins mediate interactions of human prostate carcinoma cells with endothelial cells in vitro. Prostate, 39, 108-118 (1999).

21) Anwer K, Kao G, Rolland A, Driessen WH, Sullivan SM. Peptidemediated gene transfer of cationic lipid/plasmid DNA complexes to endothelial cells. J. Drug Target., 12, 215-221 (2004).

22) Harvie P, Dutzar B, Galbraith T, Cudmore S, O’Mahony D, Anklesaria P, Paul R. Targeting of lipid-protamine-DNA (LPD) lipopolyplexes using RGD motifs. J. Liposome Res., 13, 231-247 (2003).

23) Schiffelers RM, Ansari A, Xu J, Zhou Q, Tang Q, Storm G, Molema G, Lu PY, Scaria PV, Woodle MC. Cancer siRNA therapy by tumor selective delivery with ligand-targeted sterically stabilized nanoparticle. Nucleic Acids Res., 32, e149 (2004).

24) Kunath $K$, Merdan $T$, Hegener $O$, Häberlein $H$, Kissel T. Integrin targeting using RGD-PEI conjugates for in vitro gene transfer. $J$. Gene Med., 5, 588-599 (2003).

25) Jenkins RG, Meng QH, Hodges RJ, Lee LK, Bottoms SE, Laurent GJ, Willis D, Ayazi Shamlou P, McAnulty RJ, Hart SL. Formation of LID vector complexes in water alters physicochemical properties and enhances pulmonary gene expression in vivo. Gene Ther., 10, 1026 - 1034 (2003)

26) Hart SL, Arancibia-Cárcamo CV, Wolfert MA, Mailhos C, O'Reilly NJ, Ali RR, Coutelle C, George AJ, Harbottle RP, Knight AM, Larkin DF, Levinsky RJ, Seymour LW, Thrasher AJ, Kinnon C. Lipid-mediated enhancement of transfection by a nonviral integrintargeting vector. Hum. Gene Ther., 9, 575-585 (1998).

27) Takita K, Ohsaki Y, Nakata M, Kurisu K. Immunofluorescence localization of type I and type III collagen and fibronectin in mouse dental tissues in late development and during molar eruption. Arch. Oral Biol., 32, 273-279 (1987)

28) Pearson BS, Klebe RJ, Boyan BD, Moskowicz D. Comments on the clinical application of fibronectin in dentistry. J. Dent. Res., 67, 515-517 (1988).

29) Wu TJ, Huang HH, Lan CW, Lin CH, Hsu FY, Wang YJ. Studies on the microspheres comprised of reconstituted collagen and hydroxyapatite. Biomaterials, 25, 651-658 (2004).

30) Reyes CD, García AJ. Alpha2betal integrin-specific collagenmimetic surfaces supporting osteoblastic differentiation. J. Biomed. Mater. Res. A, 69, 591-600 (2004)

31) Shigeyama Y, Grove TK, Strayhorn C, Somerman MJ. Expression of adhesion molecules during tooth resorption in feline teeth: a model system for aggressive osteoclastic activity. J. Dent. Res., 75 , 1650-1657 (1996).

32) Chowdhury EH, Nagaoka M, Ogiwara K, Zohra FT, Kutsuzawa K, Tada S, Kitamura C, Akaike T. Integrin-supported fast rate intracellular delivery of plasmid DNA by extracellular matrix protein embedded calcium phosphate complexes. Biochemistry, 44, 12273 12278 (2005)

33) Almofti MR, Harashima H, Shinohara Y, Almofti A, Li W, Kiwada H. Lipoplex size determines lipofection efficiency with or withou serum. Mol. Membr. Biol., 20, 35-43 (2003).

34) Escriou V, Ciolina C, Lacroix F, Byk G, Scherman D, Wils P. Cationic lipid-mediated gene transfer: effect of serum on cellular uptake and intracellular fate of lipopolyamine/DNA complexes. Biochim. Biophys. Acta, 1368, 276-288 (1998).

35) Halter M, Antia M, Vogel V. Fibronectin conformational changes induced by adsorption to liposomes. J. Control. Release, 101 $209-222(2005)$ 